\title{
EFFECT OF INTEGRATION BETWEEN COMPOST AND UREA FERTILIZER ON THE PRODUCTIVITY OF SAKHA 105 RICE CULTIVAR \\ Ahmed, A. A. ${ }^{1}$ and E.S. Naeem ${ }^{2}$ \\ ${ }^{1}$ Agronomy Dept., Fac. of Agric., Kafrelsheikh Univ., Egypt. \\ 2 Rice Res. \& training centre, Field Crops Res. Inst., ARC, and Egypt.
}

\begin{abstract}
Field experiments were conducted at Rice Research and Training Center, Sakha, Kafrelseikh Governorate, Egypt during two summer seasons 2010 and 2011 to study the influence of integration between compost and urea fertilizer on yield and its components of Sakha 105 rice cultivar as well as nitrogen uptake in rice grains and soil organic matter percentage. The treatments were $(0,5$ ton compost/ ha, $165 \mathrm{~kg}$ $\mathrm{N} / \mathrm{ha}, 5$ ton compost $+55 \mathrm{~kg} \mathrm{~N} / \mathrm{ha}$ and 5 ton compost $+110 \mathrm{~kg} \mathrm{~N} / \mathrm{ha}$ ).

The results revealed that compost and mineral nitrogen (urea) alone or in combination recorded increasing significant values in number of panicles/hill, number of filled grain/panicle, 1000 grain weight, grain and straw yields, nitrogen uptake and soil organic matter percentage compared with the control treatment (without fertilization) except the number of unfilled grain/panicle which recorded significantly decrease.

The results, also, showed that compost application at rate of 5 tons plus 110 $\mathrm{kg} \mathrm{N} /$ ha gave the highest values of number of panicle/hill, number of filled grains/panicle, 1000 grain weight, grain yield, straw yield, nitrogen uptake in grains and soil organic matter percentage in both seasons.

The control treatments (without fertilization) recorded the lowest values in all traits as well as yield components, grain yield, straw yield, nitrogen uptake in grain and soil organic matter percentage except the number of unfilled grain/panicle which recorded the highest values in both seasons.

In both seasons the following treatments of $165 \mathrm{~kg} \mathrm{~N} / \mathrm{ha}, 5$ ton compost plus $55 \mathrm{~kg} \mathrm{~N} / \mathrm{ha}$ and 5 ton compost plus $110 \mathrm{~kg} \mathrm{~N} /$ ha didn't significantly differ in its effect on the number of filled grains/panicle.

In both compost application at a rate $f$ tons alone or in combination with 110 $\mathrm{kg} \mathrm{N} /$ ha gave the same 1000 grain weight without significantly differences with $165 \mathrm{Kg}$ $\mathrm{N} /$ ha treatment in the second seasons.

The percentage of soil organic matter was increased with addition of compost either alone or with different levels of nitrogen which did not significantly differed in its effect on the percentage of soil organic matter.

From the results under the conditions of this study, it could be concluded that application of 5 tons compost plus $110 \mathrm{~kg} \mathrm{~N} /$ ha produced the highest grain and straw yields and is recommended as an economic treatment for increasing grain yield of rice.
\end{abstract}

\section{INTRODUCTION}

Rice (Oryza sativa L.) is one of the most important strategically crops in the world and it is one of principal nutrition crops in Egypt and in the world. Increasing the productivity of rice is very important in Egypt for increasing rice 
export which plays an effective role in Egyptian economy (Economic Sector, Ministry of Agriculture and Soil Reclamation, 2009).

Nutrition is one of the important factors to increase rice grain yield, especially nitrogen, but the utilization of mineral fertilizers lead to soil and water pollution.

The need of rice plants to nitrogen fertilizer is very important where; nitrogen is an essential element for improving rice growth and grain yield. Nitrogen can be supplied to rice plants either through mineral or organic fertilizers.

Such effects of nitrogen on rice productivity are also reported by Yoshida, (1981) who found that nitrogen addition had a positive effect on the following characters, number of panicles $/ \mathrm{m}^{2}$, number of grains/panicle, filled grains percentage and 1000 grain weight which resulted the maximum grain yield. El sheref et al. (2004) found grain yield and nitrogen content of rice crop is increased significantly with increasing nitrogen dose. Sharief et al (2006) reported that highest grain yield and yield components were produced from increasing nitrogen fertilizer up to $60 \mathrm{~kg} \mathrm{~N} / \mathrm{fed}$ in both seasons. Moreover, nitrogen uptake was also raised in rice grain by application of compost and nitrogen application (Sharma, 2006 and Lin et al., 2009).

Crop residues management and its impacts on soil organic matter is most important for sustainable soil fertility and crop productivity, compost is a resource of the organic matter which resulted from exploiting wastes through the controlled bio conversion process, compost is considered as a method for recycling and re-utilization of crop residues (Bernal et al., 1998). The use of compost can be beneficial to improve the soil physical and chemical properties and organic matter status which may increase the yield of crops. Continues application of organic manure to flooded rice soil normally causes the accumulation of organic matter (Park et al., 1990). Organic matter content of the soil has been reported to increase due to incorporation of both rice and wheat straw and it was further enhanced when supplemented with fertilizer application Singha (2003). Nasef et al. (2009) found that application of compost combined with mineral nitrogen fertilizer led to increase significantly yield, weight of 1000 grain and $\mathrm{N}$ uptake in rice grains.

Thus, the present work was designed to evaluate the response of rice cultivar Sakha 105 to integration of compost plus different rates of nitrogen as urea on rice yield and its attributes as well as soil organic matter and $\mathrm{N}$ uptake of rice grains.

\section{MATERIALS AND METHODS}

Two field experiments were carried out at the Experimental Farm of the Rice Research \& Training Centre (RRTC), Field Crops Research Institute, Sakha, Kafrelseikh Governorate, Egypt to study the effect of mineral nitrogen and compost application viz, zero, 5 tons compost/ ha, $165 \mathrm{~kg} \mathrm{~N} / \mathrm{ha}, 5$ tons compost $+55 \mathrm{~kg} \mathrm{~N} / \mathrm{ha}, 5$ tons compost $+110 \mathrm{~kg} \mathrm{~N} / \mathrm{ha}$. In both seasons the preceding crop was wheat. Soil samples were collected from experimental 
site at the depth of $0-30 \mathrm{~cm}$ from the soil surface. Compost was made from rice straw according to Abdulla (2007). The soil and compost samples were physically analyzed, according to Piper (1950) and chemically analyzed, according to Black et al. (1965). Soil and compost analysis are presented in Table 1.

The experimental design was randomized complete block with three replicates, the compost was incorporated in dry soil after complete soil preparation, while nitrogen in form of urea $(46.6 \% \mathrm{~N})$ was added in two split, $2 / 3$ of amount was added at basal before transplanting and the $1 / 3$ of amount was added at panicle initiation stage. The phosphorus in form of calcium super phosphate $\left(15.5 \% \mathrm{P}_{2} \mathrm{O}_{5}\right)$ was added after field ploughing twice then the permanent field was harrowed.

Table 1: Analysis of the experimental soil and compost.

\begin{tabular}{|c|c|c|c|c|c|c|c|c|}
\hline \multicolumn{9}{|c|}{ A: soil analysis. } \\
\hline \multirow{2}{*}{ Season } & \multirow{2}{*}{$E C_{e}(d S / m)$} & \multirow{2}{*}{ pH } & \multirow{2}{*}{$\begin{array}{l}\text { O.M } \\
(\%)\end{array}$} & \multirow{2}{*}{\multicolumn{2}{|c|}{ Texture class }} & \multicolumn{3}{|c|}{ Available (ppm) } \\
\hline & & & & & & $\mathbf{N}$ & $\mathbf{P}$ & K \\
\hline 2010 & 2.00 & 7.94 & 1.6 & \multirow{2}{*}{\multicolumn{2}{|c|}{ clayey }} & 20.23 & 10.31 & 303.1 \\
\hline 2010 & 1.99 & 8.06 & 1.5 & & & 21.89 & 10.14 & 334.3 \\
\hline \multicolumn{9}{|c|}{ B. Compost analysis } \\
\hline \multirow{3}{*}{$\begin{array}{l}\text { Means of } \\
\text { seasons }\end{array}$} & EC & \multirow{2}{*}{$\mathrm{pH}$} & \multirow{2}{*}{$\begin{array}{l}\text { O.C } \\
(\%)\end{array}$} & \multirow{2}{*}{$\begin{array}{l}\text { O.M } \\
(\%)\end{array}$} & \multirow{2}{*}{$\mathrm{C} / \mathrm{N}$} & \multicolumn{3}{|c|}{ Total (\%) } \\
\hline & $(\mathrm{dS} / \mathrm{m})$ & & & & & $\mathbf{N}$ & $\mathbf{P}$ & $\mathrm{K}$ \\
\hline & 1.89 & 7.74 & 10.3 & 17.8 & 11.2 & 0.924 & 0.132 & 0.598 \\
\hline
\end{tabular}

Rice seeds were hand broadcasted on the first week of May of both summer seasons, twenty five day-old seedlings were transplanted at $20 \times 20$ $\mathrm{cm}$ between hills and rows, The plot size was $14.4 \mathrm{~m} 2(3.6 \times 4 \mathrm{~m})$. The other cultural practices for rice cultivation were applied according to the recommendations of Rice Research and Training Center. At harvest, ten main panicles were randomly taken from each plot to determine the number of panicles/hill, number of filled grains/panicle, number of unfilled grain/panicle and weight of 1000-grains (g). In each plot an area of $7.80 \mathrm{~m}^{2}$ $(2.80 \times 3.0)$ was manually harvested, grain yield was recorded and adjusted to $14 \%$ moisture content. Grain and straw yields were converted into tons/ha and harvest index was estimated as follows:

$\mathrm{HI}=($ Grain yield/biological yield $) \times 100$.

Rice grain nitrogen content was determined using the standard Kjeldahl method according to A. O. A. C. (1970) then, rice grain nitrogen uptake in grains were computed, as follows:

Nitrogen uptake in rice grains $(\mathrm{kg} / \mathrm{ha})=$ Grain yield $(\mathrm{kg} / \mathrm{ha}) \times$ Nitrogen \% in rice grains Jackson (1967).

Also, Soil organic matter percentage was determined according to

The analysis of variance was carried out according to Gomez and Gomez (1984) for all collected data. Treatment means were compared by Duncan's Multiple Range test according to Duncan (1955). All statistical analysis was performed using analysis of variance technique by means of "MSTATC" computer software package. 


\section{RESULTS AND DISCUSSION}

\section{Yield and its components:}

Data presented in Tables 2 and 3 show the effect of compost and urea treatment and its integration on number of panicle/ hill, number of filled grains/panicle, number of unfilled grains/panicle, weight of 1000 grain, grain yield, straw yield and harvest index Sakha 105 rice cultivar during 2010 and 2011 seasons.

Data show that, a significant increase of all studied characters under all tested treatments compared with the control treatment. Data indicate that the integration between 5 tons compost plus $110 \mathrm{~kg} \mathrm{~N} / \mathrm{ha}$ recorded the highest significantly values compared with compost or urea alone for number of panicle/ hill, number of filled grains/panicle, weight of 1000 grain, grain and straw yield in both seasons except for number of unfilled grains/panicle and harvest index.

Tables $2 \& 3$ show that yield and yield components were significantly improvement due to the use of tested treatment of integration between compost and urea. Application of 5 tons compost plus $110 \mathrm{~kg} \mathrm{~N} / \mathrm{ha}$ recorded the highest yield and yield components of rice.

Table 2: Number of panicles/hill, number of filled grains/panicle, number of unfilled grains/panicle and $\mathbf{1 0 0 0}$ grain weight as affected by application of compost, mineral nitrogen and its integration in 2010 and 2011 seasons.

\begin{tabular}{|c|c|c|c|c|c|c|c|c|}
\hline \multirow[t]{2}{*}{ Treatment } & \multicolumn{2}{|c|}{$\begin{array}{c}\text { No. of panicles } \\
\text { /hill }\end{array}$} & \multicolumn{2}{|c|}{$\begin{array}{c}\text { No. of filled grains/ } \\
\text { panicle }\end{array}$} & \multicolumn{2}{|c|}{$\begin{array}{l}\text { No. of unfilled } \\
\text { grains/panicle }\end{array}$} & \multicolumn{2}{|c|}{1000 Grain weight } \\
\hline & 2010 & 2011 & 2010 & 2011 & 2010 & 2011 & 2010 & 2011 \\
\hline 0 & $14 \mathrm{e}$ & $14.27 \mathrm{e}$ & $90.6 \mathrm{c}$ & $91.03 \mathrm{c}$ & $28.13 \mathrm{a}$ & $28.47 \mathrm{a}$ & $23.50 \mathrm{c}$ & $23.67 \mathrm{c}$ \\
\hline 5 tons compost & $20.93 \mathrm{~d}$ & $20.7 \mathrm{~d}$ & $92.3 \mathrm{~b}$ & $93.07 \mathrm{~b}$ & $22.27 \mathrm{~d}$ & $22.4 \mathrm{~d}$ & $24.4 \mathrm{ab}$ & $24.59 \mathrm{a}$ \\
\hline $165 \mathrm{~kg} \mathrm{~N} / \mathrm{ha}$ & $22.2 \mathrm{c}$ & $22.7 \mathrm{c}$ & $93.1 \mathrm{ab}$ & $93.4 \mathrm{ab}$ & $23.1 \mathrm{c}$ & $23.27 \mathrm{c}$ & $24.68 \mathrm{ab}$ & $24.87 \mathrm{a}$ \\
\hline $\begin{array}{l}5 \text { tons }+55 \mathrm{~kg} \\
\mathrm{~N} / \mathrm{ha}\end{array}$ & $24.8 \mathrm{~b}$ & $25.03 \mathrm{~b}$ & $93.23 \mathrm{ab}$ & $93.57 \mathrm{ab}$ & $24.3 \mathrm{~b}$ & $24.23 \mathrm{~b}$ & $24.18 b$ & $24.09 b$ \\
\hline \begin{tabular}{|l|}
5 ton +110 \\
$\mathrm{kgN} / \mathrm{ha}$
\end{tabular} & $26.7 \mathrm{a}$ & $27.07 \mathrm{a}$ & $94.07 \mathrm{a}$ & $94.3 \mathrm{a}$ & 19.07 e & $18.83 \mathrm{e}$ & $24.88 \mathrm{a}$ & 24.78 a \\
\hline F-test & ** & ** & ** & ** & ** & ** & ** & ** \\
\hline
\end{tabular}

${ }^{*},{ }^{\star \star}$ and Ns indicate $\mathrm{p}<0.05,<0.01$ and not significant, respectively. Means of each treatment followed by the same letter are not significantly different at $5 \%$ level, according to Duncan's multiple range tests.

These results may be due to the decomposition of compost which increase the mobilization of nutrients to plants during growth stages and might produce a lot of tillers which resulted in increasing the number of panicles and improve grain filling process and so increasing weight of grains which lead to increased grain and straw yields. On the contrast, the unfertilized treatments recorded the lowest values of all traits except number of unfilled grain/panicle and harvest index; these results are in harmony with those obtained by Kalita and Sharamah (1992) and Hammad et al. (2006). As found by Sharief et al. (2006) reported that highest grain yield and yield components were produced from increasing nitrogen fertilizer up to $60 \mathrm{~kg}$ 
$\mathrm{N} / \mathrm{fed}$ in both seasons. Nasef et al. (2009) found that application of compost combined with mineral nitrogen fertilizer led to increase significantly yield and weight of 1000 grain. The highest 1000 grain weight value was recorded at $100 \mathrm{Kg}$ urea plus 6 tons compost as compared with the control, while the lowest 1000 grains weight value was obtained when no fertilizer was added as observed by Begum et al. (2001).

Table 3: Grain yield, straw yield and harvest index as affected by application of compost, mineral nitrogen and its integration in 2010 and 2011 seasons.

\begin{tabular}{|c|c|c|c|c|c|c|}
\hline \multirow{2}{*}{ Treatments } & \multicolumn{2}{|c|}{ Grain yield (t/ha) } & \multicolumn{2}{|c|}{ Straw Yield (t/ha) } & \multicolumn{2}{|c|}{ harvest index } \\
\hline & 2010 & 2011 & 2010 & 2011 & 2010 & 2011 \\
\hline 0 & $7.05 \mathrm{e}$ & $7.19 \mathrm{~d}$ & $7.33 \mathrm{e}$ & $7.66 \mathrm{~d}$ & $0.49 \mathrm{a}$ & $0.49 \mathrm{a}$ \\
\hline 5 tons compost & $10.12 \mathrm{~d}$ & $10.64 \mathrm{c}$ & $12.52 \mathrm{~d}$ & $12.61 \mathrm{c}$ & $0.45 \mathrm{~b}$ & $0.46 \mathrm{~b}$ \\
\hline $165 \mathrm{~kg} \mathrm{~N} / \mathrm{ha}$ & $10.73 \mathrm{c}$ & $10.66 \mathrm{c}$ & $12.95 \mathrm{c}$ & $13.3 \mathrm{~b}$ & $0.45 b$ & $0.44 \mathrm{c}$ \\
\hline 5 tons $+55 \mathrm{~kg} \mathrm{~N} / \mathrm{ha}$ & $11.59 \mathrm{~b}$ & $11.45 \mathrm{~b}$ & $13.83 \mathrm{~b}$ & $13.71 \mathrm{~b}$ & $0.46 \mathrm{~b}$ & $0.45 \mathrm{~b}$ \\
\hline 5 tons $+110 \mathrm{kgN} / \mathrm{ha}$ & $12.28 \mathrm{a}$ & $12.16 \mathrm{a}$ & $14.71 \mathrm{a}$ & $14.52 \mathrm{a}$ & $0.45 b$ & $0.46 \mathrm{~b}$ \\
\hline F-test & ** & $\star \star *$ & $\star \star$ & $\star \star *$ & $\star \star$ & $\star \star \star$ \\
\hline
\end{tabular}

${ }^{*},{ }^{\star *}$ and Ns indicate $\mathrm{p}<0.05,<0.01$ and not significant, respectively. Means of each treatment followed by the same letter are not significantly different at $5 \%$ level, according to Duncan's multiple range tests.

\section{Nitrogen uptake in rice grains:}

Data in Table 4 show that the effect of compost and urea alone or in its integration on nitrogen uptake in rice grains in both seasons.

Data reveal that grain nitrogen uptake were gradually increased by application of 5 tons compost/ha and urea alone or in its integration. The lowest values of nitrogen uptake in grains resulted from unfertilized treatment then followed by gradually increasing from application of 5 tons compost, 165 $\mathrm{kg} \mathrm{N} / \mathrm{ha}, 5$ tons compost $+55 \mathrm{~kg} \mathrm{~N} / \mathrm{ha}$ up to 5 tons compost $+110 \mathrm{~kg} \mathrm{~N} / \mathrm{ha}$ in both seasons, where the highest nitrogen uptake in rice grains was obtained by application of 5 tons compost plus $110 \mathrm{~kg} \mathrm{~N} / \mathrm{ha}$. These findings might be attributed to increasing nitrogen availability which in turn increased nitrogen absorption and translocation, consequently, increased grain $\mathrm{N}$ uptake. These findings are in harmony with those obtained by Nasef et al. (2009) which found that $N$ in grains was increased significantly with the application of compost in combination with different levels of $\mathrm{N}$ mineral fertilizer especially with the highest levels as compared with application of mineral $\mathrm{N}$ fertilizer alone. Hemalatha and Balasubramanian (2000) and Mirza et al. (2005) reported that nitrogen uptake in rice grains was significantly increased by organic fertilizers application. Sharma (2006) and Lin et al. (2009) reported that nitrogen uptake was also raised in rice grain by application of compost and increasing nitrogen application.

\section{Soil organic matter percent:}

Soil organic matter percentage as affected by compost application, mineral nitrogen as urea and its integration are presented in Table 4.

The data show that soil organic matter percentage increased by application of compost either applied alone or in combinations with different levels of mineral nitrogen compared with the control treatment. The results in 
both seasons revealed that soil organic matter percentage gave the lowest values as observed at unfertilized treatment while the highest values were obtained from the integration between 5 tons compost plus $110 \mathrm{~kg} \mathrm{~N} / \mathrm{ha}$. Data also show that in the both season the 5 tons compost treatment did not significantly differ from 5 tons compost plus $55 \mathrm{~kg} \mathrm{~N} / \mathrm{ha}$. Such results are in agreement with those obtained by Sharma (2006) and El-Sedfy et al. (2008) reported that addition of compost was accompanied by a significant increase in soil organic matter compared with the untreated soil (control), Hammad et al. (2006), Awad (2001) and El-Kouny et al (2004) reported that soil organic matter percentage was increased by using organic fertilizer or compost.

Charkrabarti et al. (2003) studied the integrated applications of organic and inorganic fertilizers and reported that inorganic fertilizers may meet the demand of mineral nutrition by microbes but cannot provide carbon, which is a major constituent of microbial cells. Integrated applications of organic and inorganic materials provide balanced mineral nutrition as well as carbon.

Table 4: Nitrogen uptake in rice grains and Soil organic matter percentage as affected by application of compost, mineral nitrogen and its integration in 2010 and 2011 seasons.

\begin{tabular}{|l|c|c|c|c|}
\hline \multirow{2}{*}{ Treatment } & \multicolumn{2}{|c|}{$\mathbf{N}$ uptake (Kg/ha) } & \multicolumn{2}{|c|}{ O.M (\%) } \\
\cline { 2 - 5 } & $\mathbf{2 0 1 0}$ & $\mathbf{2 0 1 1}$ & $\mathbf{2 0 1 0}$ & $\mathbf{2 0 1 1}$ \\
\hline $\mathbf{0}$ & $28.94 \mathrm{e}$ & $29.05 \mathrm{e}$ & $1.49 \mathrm{c}$ & $1.52 \mathrm{c}$ \\
\hline $\mathbf{5}$ tons compost & $49.02 \mathrm{~d}$ & $49.91 \mathrm{~d}$ & $1.51 \mathrm{bc}$ & $1.63 \mathrm{ab}$ \\
\hline $\mathbf{1 6 5} \mathbf{~} \mathbf{~ N} / \mathbf{h a}$ & $50.3 \mathrm{c}$ & $50.45 \mathrm{c}$ & $1.55 \mathrm{bc}$ & $1.59 \mathrm{bc}$ \\
\hline $\mathbf{5}$ tons +55 $\mathbf{~ g ~ N / h a}$ & $51.43 \mathrm{~b}$ & $51.54 \mathrm{~b}$ & $1.57 \mathrm{~b}$ & $1.62 \mathrm{ab}$ \\
\hline $\mathbf{5}$ tons + 110 $\mathbf{~ g N / h a ~}$ & $54.27 \mathrm{a}$ & $54.33 \mathrm{a}$ & $1.67 \mathrm{a}$ & $1.70 \mathrm{a}$ \\
\hline F-test & ${ }^{* *}$ & ${ }^{* *}$ & ${ }^{* *}$ & ${ }^{*}$ \\
\hline
\end{tabular}

${ }^{*},{ }^{\star \star}$ and Ns indicate $\mathrm{p}<0.05,<0.01$ and not significant, respectively. Means of each treatment followed by the same letter are not significantly different at $5 \%$ level, according to Duncan's multiple range tests.

\section{REFERENCES}

A.O.A.C. (1990). Official Methods of the Analysis. Association of Official Agricultural Methods. 15 th Edition, Published by Association of Official Analytical Chemists, Arlington, Virginia, USA.

Abdulla, H. (2007). Enhancement of Rice Straw Composting by Lignocellulolytic Actinomycete Strains. International Journal of Agriculture \& Biology, Vol. 9, No. 1, $206-109$.

Sharma, A. K. (2006) a handbook of organic farming .Agrobios India reprinted, page (10-11).

Awad, M.Y.M. (2001) Effect of some organic compounds on soil properties and plant growth. M.Sc.Thesis, Fac. of Agric. Minufiya. Univ., Egypt.

Begum, S.; M. M. Rhman; M.J. Abdin Main; M.R. Islam and M. Uddin. (2001). Effect of nitrogen supplied from manure and fertilizer on the growth, yield and nutrient uptake of rice. Online Journal of Biological Sciences 1 (18): 708-710. 
Bernal, M.P; J. Cegara; A. Roig; M. A. Sanchez-Monedero and C. Paredes (1998). Composting of organic wastes as a strategy as for production high quality organic fertilizers. $18^{\text {th }}$ International Conference on Management Strategies for Organic Waste Use in Agriculture. Rennes, France, 26-29 May, 1998.

Black, C; D. Evans; L. Ensminger and F. Clark (1965). Methods of soil analysis (Chemical and Microbiological) properties, Part 2). Amer. Soc. Agronomy, Inc. Pub., Madison, Wisconsin, U.S.A.

Charkrabarti, K.; Bhattch, A. and A. Charkraborty (2003) Effect of metal contaminated organic wastes on microbial biomass and activities. In. Ahmed.I; S. Hayat and J.Pichet (Ed). Heavy metals contamination of soil. Ball State University .Natural Resources and Environmental Management Muncie, IN. USA.A.C 386206.

Duncan, B.D. (1995) Multiple Range and Multiple F. Test. Biometrics.11: 142.

Economic Sector, Ministry of Agriculture and Soil reclamation (2009).

El- sheref, E.El; M. Heam, A. galeah and M. Abd El-hameed (2004). Effect of nitrogen levels, hill spacing and rice cultivar mixtures on some rice characters. J. Agric. Sci. Mansoura univ., 29: 535 -552.

El-Kouny, H.M; A.M. El- Assar; and S.G Mohamed (2004) Effectivness of natural organic amendments, biologically actived compost, and mineral fertilization sources of potassium in improving soil properties and productivity of Zaghlow CV. data plam in calcareous soil Assuite.J.Agric. 35 (2): 195-214.

El-Sedfy, O. F.; R. Abd El-Hamid, Azza and A.A. Mahmoud (2008) Impact of compost and phosphate fertilizers utilization on phosphorus availability and some crops productivity on sandy soils. Minufiya J. Agric. Res. Vol. 33 No.4: 1031-1053.

Gomez, K. and A. Gomez (1984) Statistical Procedures of Agricultural Research. John Wiley and Sons. Inc., New York, U.S.A.

Hammad, S.; A. Ghanem and E.S. Naeem (2006).Grain yield of lowland (Oriza Sativa) as influenced by integrated use of urea and rice straw fertilizer. Soil Sci., Dep. of Agric., Mansoura Univ., Egypt.

Hemalatha, M.T and R.Balasubramanian (2000). Effect of organic sources of nitrogen on productivity, quality of rice and soil fertility in single crop wetland. Ind. J. Agron., 45 (3):564-567.

Jackson, N. (1967). Soil Chemical Analysis. Prentice Hall Inc. Englewood Cliffs S.N.S.

Kalita, M.C. and N.N. Sharamah (1992) Effect of nitrogen level and mulch on yield and yield attributing characters of summer rice under the rainfed condition. Ind. J. Agron., 37 (4): 690-693.

Lin, G.; D. Zhaw, M. Chen and Q. Zhang (2009). Effects of plant density and nitrogen application rate on grain yield and nitrogen uptake of super hybrid rice. Rice Sci., 16(2): 138-142.

Mirza, B.B.; M.S. Zia; N. Szombathovan and A. Zaujec (2005) Rehabilitation of Soils through Environmental Friendly Technologies: Agricultura Tropica ET Sub Tropica, Vol. 38(1). 


\section{Ahmed, A. A. and E.S. Naeem}

Nasef, M.A.; Kh. A. shaban and Abd F. El-Hamid, Amal (2009) effect of compost tea and bio-fertilizer application on some chemical soil properties and rice productivity under saline soil condition. J. Agric .Sci., Mansoura univ., 34 (4): 2609 -2623.

Park, Y.D.; S.K. Lee; K.N. Hwang and C.S. Park (1990). Fate of fertilizer nitrogen as affected by application of rice straw and compost in flooded rice soils. Transactions $14^{\text {th }}$ International Congress of Soil Science, Kyoto, Japan August, Vol. IV: 349-354.

Piper, C. (1950) Soil and plant analysis Inc. Soci., Pub. Inc., New York, U.S.A.

Sharief, A. E.; S.E. El-Kalla; A.T.El-kassaby; M.H. Ghonema and G.M. Abdo (2006) Effect of Bio chemical fertilization and times of nutrients foliar application on growth, yield and yield components of rice. Journal of Agronomy 5 (2): 212-219.

Singha, D. D. (2003). Management of crop residues in summer rice and its effect on the soil properties and crop yield. Crop-Res. Hisar 25(1): 191 - 193. Rizona Soils. Soil Sci., 68: 541-462.

Yoshida, S. (1981). Fundamentals of rice crop science. International Rice Research Institute, Los Banos, Philippines: 135-146.
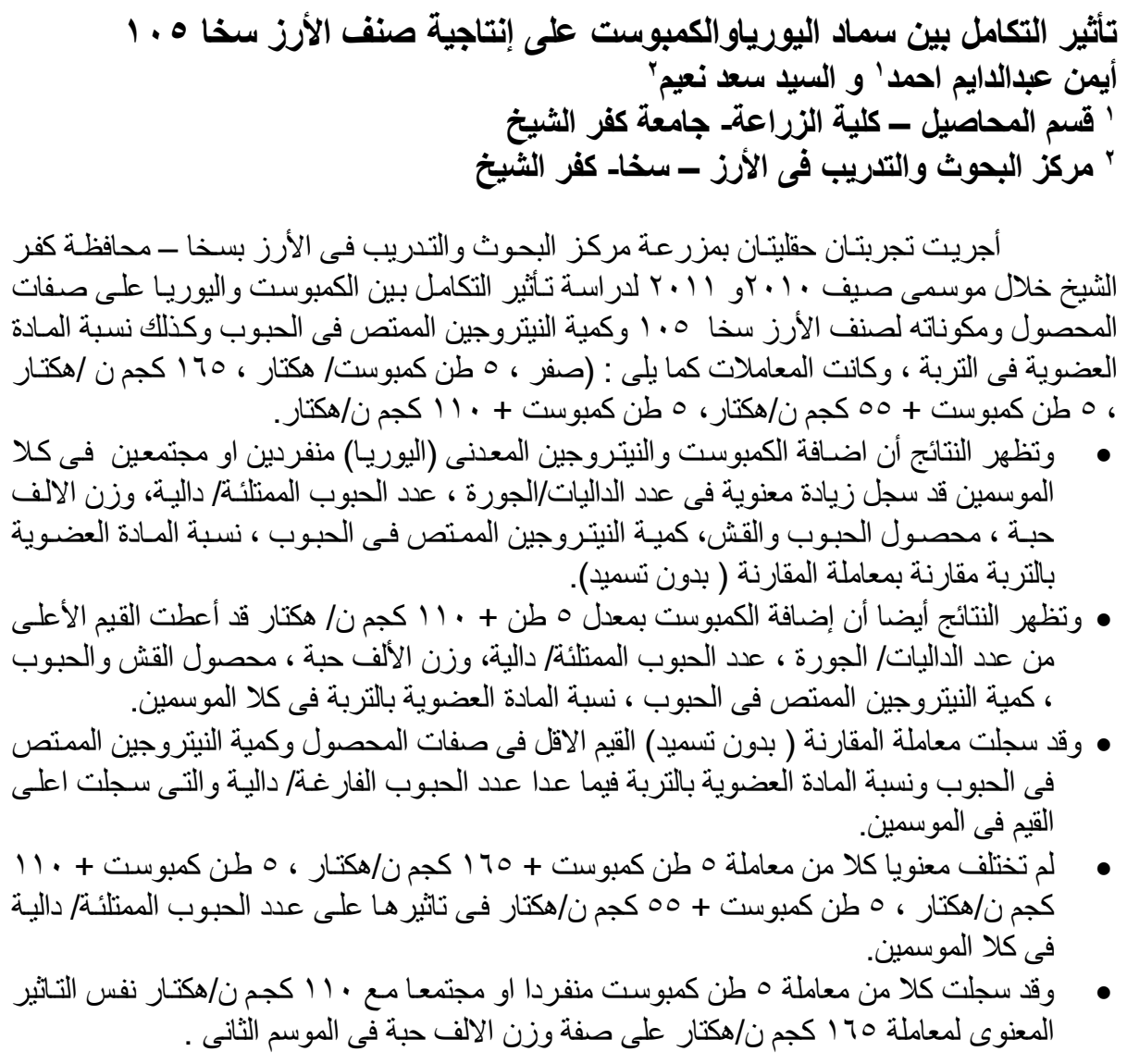
وقد أظهرت الدر اسة وجود تحسن معنوى فى نسبة المادة العضوية بالتربة نتيجـة إضـافة الكمبوست التهات

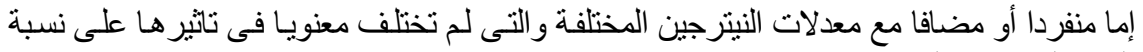
المادة العضوية بالتربة.

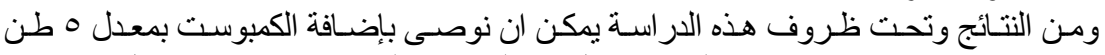

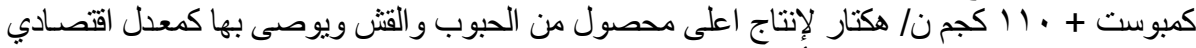

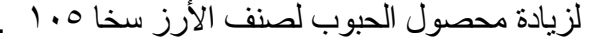

كلية الزراعة - جامعة المنصورة كلية الزراعة - جامعة كفر الثيخ الثراعة
قام بتحكيم البحث

أ.ـد / احمد نادر السيد عطيه

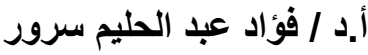

